zealously supported in the extensive plans of observation arranged by him, by the other officers of the establishment. The great comet of 1874 was followed with the large refractor of the Argentine Observatory (which, Dr. Gould informs us, is an Ir-inch by Fitz, of New York) until the $x 8$ th of October, the comet having been first seen there, in the morning twilight on July 27 ; at the last observation it was within about $12^{\circ}$ of the South Pole. [Our last remarks on this comet should have been headed Comet, I 874 (III.)].

THE LATE W. F. HENWOOD, F.R.S.

THIS distinguished mining geologist, who died at Penzance last week, in his seventy-first year, was originally a clerk in the employment of Messrs. Fox, of Falmouth, to whose counsel he was considerably indebted in his early scientific work. By very great industry and careful observation he acquired an unsurpassed knowledge of the mineral deposits of Cornwall and Devon, and after fulfilling a succession of important mining appointments, he became Assay Master of tin to the Duchy of Cornwall. This post being abolished, Mr. Henwood's great experience was utilised in reporting upon and developing a number of mining districts in South America, Canada \&c. : and after the cessation of his travels, he lived at Penzance in comparative retirement. His great works are the fifth and eighth volumes of the "Transactions of the Royal Geological Society of Cornwall," devoted respectively to the metalliferous deposits of Cornwall and Devon, and to those of the foreign countries he had visited. But his scientific writings, besides these, were very numerous; a list of them occupies seven columns in the "Bibliotheca Cornubiensis."

As a scientific man Mr. Henwood was characterised by indefatigable labour, great caution, love of accuracy, and moderation of expression. In his publications he scarcely ever mentions a fact of any kind which had not come under his own experience, without giving the authority for it. Thus many of his writings are marvels of copious reference. He persisted in doing everything with this extraordinary amount of labour and care up to the last, notwithstanding that he suffered for many years from a very painful heart-disease. His scientific work ceased only with his death. So long as he could sustain even an hour's intellectual effort during the day, that was devoted to the arrangement of his stores of facts and observations. I believe that scarcely one of his cherished objects in this respect remains unfulfilled.

Mr. Henwood's address to the Royal Institution of Cornwall in $187 \mathrm{I}$, extending, with references, to sixty-five pages, affords ample evilence of the value of his observations and of his scientific ability. It includes the most admirable and complete compendious account of the mode of occurrence of metalliferous deposits in Cornwall which has yet appeared, and is characterised by that absence of theoretical assumption which specially marked him as an observer. The orderly arrangement of accurately-cbserved facts was his object; theorising he had little affection for; suspended judgment on unproved theories was his consistent attitude.

In personal character $\mathrm{Mr}$. Henwood won the high regard of all who knew him intimately. His acquaintance with men and manners was so great and varied, his memory so retentive, and his conversational style so simple and lucid, that to talk with him was one of the most delightful and instructive of intellectual recreations. His estimate of his own labours and merits was unaffectedly modest, although he would resist, if possible, any unfair representation of his work.

In the spring of the present year the Murchison Medal of the Geological Society was awarded to Mr. Henwood. An extract from a letter written by him to a friend on this subject may fitly close this notice: "Mr.
Evans's far too flattering estimate of my poor labours was most kindly intended. Although the distinction cannot but afford me pleasure, this is as nothing compared with the kind, and even affectionate, congratulations of yourself and my other friends. All these I carefully preserve, as they will show what I have done far better (though in an undeservedly favourable light) than the mere official record."

G. T, BETTANY

\section{THE INTERNATIONAL CONGRESS AND EXHIBITION OF GEOGRAPHY}

THE Geographical Exhibition continues to have increasing success, although the price of admission has been raised, except for schools, for which the original price, a penny a head, has been kept, and the galleries are crowded with children under the guidance of their teachers. It is said that all the soldiers of the garrison of Paris will be marched through the galleries under the guidance of their officers, when the Congress is over. The Exhibition will be prolonged to the end of the month.

Several improvements have been made in the English section since our last notice. Examples of the several maps published by the Ordnance Survey have been exhibited from an inch to ten feet per mile. Although completed only at a late period, the exhibition of the Geological Survey of Great Britain has been very successful ; an immense number of maps have been exhibited, and are said to be the finest in the whole exhibition building. We might refer to a nimber of other exhibits honourable to English enterprise, but we must confess that Russia has carried the day, not on account of her private enterprise, but in consequence of the strenuous action of the Government. It is very likely that St. Petersburg will be chosen by common consent for the seat of the next geographical exhibition.

M. Glœsener, member of the Royal Acadeniy of Sciences of Belgium, exhibits a chronograph available for registering the flight of projectiles as well as for recording astronomical observations for the determination of longitude. The cylinder can be put into rotation at the rate of four turns in a second or one turn in thirty seconds, accord. ing to the order of phenomena. It requires only the power of Daniell cells and ordinary magnet needles, without any electrical spark. It is very cheap, compact, and easy to set in operation.

The Rysselberghe self-registering meteorograph has been admitted, as we have already noticed, to supersede any similar instrument in existence. Copper plates engraved automatically can be used in printing, having turned into relief by the processes already described.

M. Lynström, of the University of Helsingfors, has sent to the Geographical Exhibition an interesting instrument invented by him to demonstrate that auroræ are produced by electrical currents passing through the atmosphere in the polar regions. The apparatus is put daily into operation by M. Mohn, the director of the Meteorological service of Sweden, and it was constructed at the expense of Mr. Oscar Dickson, the Gottenburg merchant, who has fitted out the Swedish Polar Expedition under Prof. Nordenskiöld. Our illustration will give an idea of the apparatus.

$A$ is an electrical machine, the negative pole being connected wtih a copper sphere and the positive with the earth.

$\mathrm{S} \mathrm{S}^{\prime}$ are of ebonite as well as $\mathrm{R} \mathrm{R} d d$, so that $\mathrm{B}$ is quite isolated as the earth in the space. $B$ is surrounded by the atmosphere. $a^{\prime} a^{\prime} a^{\prime} a^{\prime} a^{\prime} a^{\prime}$ are a series of Geissler tubes with copper ends above and below. All the upper ends are connected with a wire which goes to the earth, consequently a current runs in the direction of the arrows through the air, and the Geissler tubes become luminous when the electrical machine is set into operation. 
These Geissler tubes represent the upper part of the atmosphere which becomes luminous when the aurora borealis is observed in the northern hemisphere. The phenomena produced by the Lynström apparatus are quite consistent with the theory advocated by Swedish observers that electrical currents emanating from the earth and penetrating into the upper regions produce auroræ in both hemispheres. The experiment differs from the

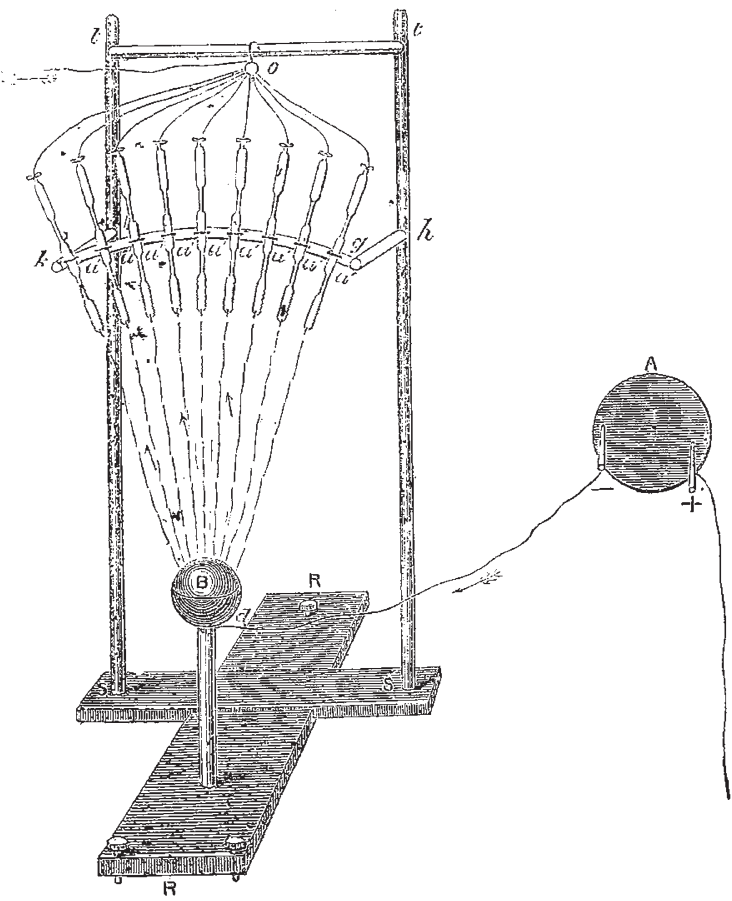

apparatus of M. De la Rive, who placed his current in wacuo, and did not show the property of ordinary atmospheric air of allowing to pass unobserved at the pressure of $760 \mathrm{~mm}$. a stream of electricity which illuminates a rarified atmosphere. The experiment is most attractive, and hundreds of persons witness it every day.

The arrangements for the general daily meetings of the Congress are very good. Every morning the seven sections meet at nine o'clock and discuss the subjects placed on the ordre du jour. At three o'clock all the members meet in the Salle des Etats, under the presidency of one or other of the presidents of the various geographical societies of Europe. No discussion takes place at these general meetings, but the presidents of sections report on the discussions which have taken place at the morning sitting. Consequently, all who attend the evening meeting obtain a summary of the transactions of the day. Visitors are admitted to the general meetings only. Sometimes several sections meet together in the morning to deliberate on subjects of common interest, and general deliberations will be proposed at the end of the session.

A subject very much discussed has been the adoption of a first meridian. Struve proposed Greenwich. One of the most interesting questions has been on the substitution of the centesimal for the sexagesimal division of the quadrant, or of the entire sphere. It was decided by twenty-three to seven in favour of the centesimal division of the quadrant, reserving the larger question of its extension to the entire sphere till the matter is brought before the general meeting. The present system found no advocate. M. Bousquet de la Grie's proposal for dividing the compass into 360 points, to be reckoned from left to right, has also been approved.
The question "of ascending currents in the atmosphere has been seriously discussed, M. Faye maintaining that only descending waterspouts have been observed. $M$. Faye's theories, however, have found very little support. The general opinion, as supported by Mohn and others, being that no descending current can be observed without an ascending one, so that there is a circular rotation of the atmosphere in altitude, and the upper strata are in constant communication with inferior strata of the atmosphere.

A commission has been appointed on the question of a great Transiberian railway. The Russian colonel Bogdanovitch spoke in favour of a line by Ekaterineburg and Tiumen, which has the advantage of putting Europe into communication with the large rivers of Southern Siberia. He said that the Russian government had decided upon the construction of a section $\mathrm{x}, 000$ miles long.

Lectures were delivered by MM. Gerard Rohlfs, Nachtigall, and Schweinfurth, on the exploration of Central Africa, and these intrepid explorers answered a number of questions in reference to their travels.

On Sunday about 300 members, amongst them a rumber of ladies, visited Compiègne to see the museum of Cambodian antiquities, collected by M. Delaporte, a lieutenant in the French national service, and exhibited in the ex-imperial palace inhabited by Napoleon III. M. Delaporte published in I873, at Hachette's, a large work in two folio volumes, with an immense number of illustrations, and a graphic atlas in chromolithography. The King of Cambodia, having been admitted to a French protectorate, sent a number of antiquities to Compiègne, where M. Delaporte has organised the museum which was visited on Sunday. M. Delaporte himself was in attendance to explain the manner in which all those astonishing relics of an unknown part had been brought to light. These monuments have undergone a systematic destruction, it is supposed, in the fifth century B.C, and are mostly concealed in the centre of immense forests which have grown since that time, and situated in infested districts which are mostly inhabited by tigers and poisonous snakes. It was M. Jules Simon who had the honour to grant the mission whose results have been so fruitful, and the zeal elicited by explorers was so great that the credit of 10,000 francs granted was almost sufficient to collect a quantity of stones which fill the basement of the Palace.

Of the juries appointed by the Geographical Congress five have given their awards, while the remaining two have not yet come to any decision. Letters of distinction, the highest reward the Congress can bestow, have been conferred upon England-namely, in Group I upon the Topographical and Trigonometrical Office of India and the Ordnance Survey Office of Southampton; in Group 2 upon the Hydrographic Office ; in Group 3 upon the Meteorological Office, the office of Geological Survey of Great Britain, and the Royal Geographical Society of London; in Group 4 upon the Palestine Exploration Fund for maps and plans and photographic reliefs. Letters of distinction have also been conferred in the United. States upon: Group 2 the Navy Department; Group 3 the United States Signal Service, and upon Mr. William Martin for a description of the island of Hawai. Numerous first-class medals have, moreover, been conferred upon Englishmen and Americans.

\section{THE MANATEE AT THE ZOOLOGICAL} GARDENS

F those mammalian animals which, instead of making their customary abode the land, reside in water either fresh or selt, the Seals and Porpoises are best known by sight to the public at large. These two just named animals are representatives of two great zoological groups, the Pinnipedia and the Cetacea, the relationships 